\title{
Towards Sustainable Dispute Resolution: A Framework to Enhance the Application of Fast Track Arbitration in the Malaysian Construction Industry
}

\author{
Nur Khodijah Muhammad Fadhlullah $\mathrm{Ng}^{1}$, Zulhabri Ismail ${ }^{1 *}$, Fashiha Hashim ${ }^{1}$
}

${ }^{1}$ Faculty of Architecture, Planning and Surveying, Universiti Teknologi MARA (UiTM), Shah Alam, 40450, MALAYSIA

*Corresponding Author

DOI: https://doi.org/10.30880/ijscet.2019.10.02.009

Received 15 June 2019; Accepted 26 November 2019; Available online 31 December 2019

\begin{abstract}
There is a significant increase in the role of construction industry for the last few decades accompanied by a considerable upsurge in the construction disputes as well. Arbitration has constantly become popular, and strengthened its position as it can be settled within the stipulated time compared to litigation. However, the arbitral process takes longer which leads to fast track arbitration. Fast track arbitration is designed to enable arbitration to proceed quickly, which can minimize the time and optimize the cost. The proliferation number of construction disputes from construction industry has emerged the importance in using fast track arbitration as one of the preferable Alternative Dispute Resolution (ADR). Regardless of frequent developments made to overcome the issues, however, there is an insignificant figure on the usage of fast track arbitration in the construction industry. This paper therefore aims to elicit a better understanding of the application of fast track arbitration in the Malaysian construction industry. Twenty (20) total number of participants - construction arbitrators - were interviewed to record their experience. A proposed framework for the application of fast track arbitration has been constructed from the responses to expand the current definition. With the changing practice environment, construction arbitrators need to be aware of the existing fast track arbitration which is crucial in ensuring its efficiencies to be applied in Malaysia, and this paper is intended to aid this process.
\end{abstract}

Keywords: Arbitration, fast track arbitration, alternative dispute resolution (ADR), construction arbitrators

\section{Introduction}

The consistent growth of the construction industry in the past few years driven mainly by government projects as part of the Economic Transformation Program ("ETP") has continued to rise many construction - related disputes. Some problems in the construction industry were speculative without sufficient financial capital, the extensive period of time and the high cost of existing dispute resolution mechanisms, and the unequal bargaining powers between parties, which have led to abuse. These problems bring undesirable effects to the industry, consumers and ultimately the economy. Insolvent subcontractors and abandoned projects are just some of the consequences.

Malaysian construction disputes are traditionally resolved in arbitration in the normal courts of law (Lim, 2014). It is further added that the construction disputes are often technically complex, involving mixed issues of fact and law. Both modes of dispute resolution have, in recent years, been increasingly perceived as inadequate and unsatisfactory by users especially in respect of cost and time taken to dispose of the disputes. Undoubtedly, Alternative Dispute Resolution (ADR) is known as a modern concept which has been developed to settle dispute speedily and amicably specially related to commercial transaction/contract in the construction industry (Karape \& Joshi, 2018). Arbitration is claimed to be a 
time-consuming dispute resolution method because the process normally takes longer to be resolved, similar to litigation which leads to the approach of using fast track arbitration (AIAC, 2018).

Fast track arbitration was firstly introduced by the newly named Asian International Arbitration Centre (AIAC) previously known as Kuala Lumpur Regional Centre for Arbitration (KLRCA) in the year 2010, and revised in 2012. It was designed for parties who wish to obtain an award in the fastest way with minimal costs. The rules provide that arbitration (with a substantive oral hearing) must be completed within a maximum of 160 days and tried before a sole arbitrator unless parties prefer a larger panel (AIAC, 2018).

Besides, there are several international institutions that have developed their own sets of "Fast Track" Arbitration rules. The list below is the examples of global institutions, such as ICC (International Chamber of Commerce) regulartrack rules, Art. 24: The award must be rendered within six months from the terms of reference. DIS (The German Institution of Arbitration) fast-track rules, Sec. 1.2: The proceedings cannot exceed six months from the statement of claim or nine months in case of a three-member tribunal. SCC (Stockholm Chamber of Commerce) regular-track rules, Art. 37: The award must be rendered within six months from the transmission of the case to the arbitrator. Swiss fasttrack rules, Art. 42(1): The award must be rendered within six months from the transmission of the file to the tribunal. CIETAC (The China International Economic and Trade Arbitration Commission) regular-track rules, Art. 42(1): The award must be rendered within six months from the composition of the tribunal. CPR (The International Institute for Conflict Prevention \& Resolution) draft fast-track rules: The award must be rendered within six months from the commencement of the arbitration (Guney, 2018).

In Malaysia, arbitration has been divided into two folds which are domestic arbitration and international arbitration. Domestic arbitration was created based on the English Arbitration Act (2006) that was successfully amended in 2011. The international arbitration has regarded Malaysia as a signatory to the 1968 UNCITRAL New York Convention which enables the AIAC awards to be enforceable in 48 countries (AIAC, 2018). Based on the case analysis published in AIAC's Newsletter in early February 2017, it was revealed that the period from 1978 to 2010 has a total of 22 cases. By 2016 , it recorded a staggering number of 618 cases, a $96.4 \%$ growth since 2010 , making a total of $71 \%$ including arbitration and fast track arbitration (Rajoo, 2018).

In relation to the above matter, this paper seeks to propose a framework for the application of fast track arbitration in the Malaysian construction industry. Correspondingly, it perceives on the importance of the usage of fast track arbitration based on the experiences and perspectives of the respondents.

\section{Conflicts and Disputes in Construction}

The proliferation of construction projects has widened its extensive linkages with the rest of the economy that involves the manufacturing industries and others as well. During the implementation of the project, all parties involved have similar goals, as the project is urged to complete according to time, budget and the quality. Prior to that, the concept of disputes needs to be address clearly as a platform to ensure the consistency. Conflict is inevitable in any human relationship (Fenn, Lowe, \& Speck, 1997). In the construction process, there is involvement of various parties, including owners, designers, suppliers, contractors and construction managers that work together as a team to deliver a project based on the time frame given. The larger the price tag and scope of a construction project, the higher the possibilities of misunderstandings and disagreements between the contracted parties (Charehzehi, Chai, Md Yusof, Chong, \& Loo, 2017). Due to the complexity of the construction industry itself, it is closely linked to disputes (Nee, Nadarajan, \& Whyte, 2013).

\section{Litigation and Alternative Dispute Resolution (ADR)}

Construction industry disputes are seen as common and the monetary amounts in dispute relatively and frequently quite high. Additionally, disputes in the construction industry are often quite fragmented and complex, thus making it difficult to present issues clearly to non - technical triers to fact. This particular industry has be characterized to be confrontational and antagonistic as it is relying on the contract specification in details with close performance monitoring.(Cox \& Thompson, 1997; Saad, Jones, \& James, 2002). In the same vein, Tazelaar \& Snijders (2010) advocate the typical nature of the competitive and tough world that construction industry has apparently produced increasing level of conflicts and disputes resulting in a dominant blame culture and a strong tendency towards the use of litigation and alternative dispute resolution. In particular, the detail of litigation and type of alternative dispute resolution are discussed below.

\subsection{Litigation}

Construction litigation 'enjoys' an unenviable reputation for being highly complex, extremely time - consuming and prohibitively expensive (Gerber \& Serra, 2011). Construction litigation usually involves complex technical issues, several parties (whose involvement typically raises intricate proportionate liability issues) and a large volume of discoverable documents. These aspects of construction litigation all significantly increase the potential for lengthy delays and disproportionate costs. It is in the nature of the construction litigation that its resolution may require technical evidence. 
Construction disputes tend to revolve around issues of quality, time or money, and all of these generally require expert evidence.

More often than not, construction litigation involves more than two parties, all of whom perform a role in completing the work. Examples of parties other than the builder and owner who could be involved are 'the contract administrator, insurer, subcontractor, consultants such as engineer, architect or quantity surveyor and statutory authorities. These parties have different interests, claims and potential liabilities, all of which may need to be explored before a construction dispute can be resolved. It is axiomatic that with the involvement of more parties comes a corresponding increase in the time required to examine the merits of each claim and defense, the number of experts needed, the length of the hearing and, ultimately, the costs.

\subsection{Arbitration}

The practice of construction arbitration has been boosted by general acceptance of the main employers to refer disputes to arbitration. This general acceptance is evident from the incorporation of arbitration clauses in their standard forms of construction contracts (Besaiso, Fenn, \& Emsley, 2018).

Arbitration in an optional private process for settling disputes takes place within a complex, and is a vitally important international legal framework. With the growth of international trade, the increasing complexity of international transactions and the disappointment with the traditional method of settling disputes, arbitration comes in vogue, implying that arbitration is distinct from Alternative Dispute Resolution forms. It is a dispute settlement procedure that, like litigation in the State courts, leads to a final and binding result that will be given execution by the courts. In addition, the main difference between arbitration and litigation is that arbitration is consensual and the final award may treat only those matters that are referred to arbitration by the parties.

Arbitration is known to be a method of dispute resolution involving one or more neutral third parties who are usually agreed to by the disputing parties and whose decision in binding (Garner, 1999).

\subsection{Adjudication}

The term adjudication is very much associated with the construction industry as one of the options in alternative dispute resolution to manage conflicts and dispute (Mohamed Nasir, Ismail, \& Muhammad Fadhullah Ng, 2018). The introduction of statutory adjudication is reported to be implemented due to the published Latham Report in the year 1994 (Gaitskell, 2007). The informal use of adjudication in the construction industry has been found even in the 1980s in the cases of contractual adjudication (Gaitskell, 2007). However, resistances from paymasters; the main contractor or employers as they have the higher power and negotiating strength, are making adjudication in contracts' clause of little importance.

The only way to make sure that there is a real impact in implementing adjudication is by having a legislation that makes it a compulsory entity to be complied by all parties in the construction industry. The first statutory adjudication being implemented was the Housing Grants, Regeneration and Construction Act 1996 (HGRCA) that came into effect in the year 1998 by the Parliament of the United Kingdom (Mohamed Nasir et al., 2018). The purpose of this paper is to identifying the possible issues that might be faced by the Construction Industry Payment and Adjudication Act 2012 (CIPAA) as a newly legislated Act in Malaysia and possible corrective measures that could be undertaken to enhance its effectiveness (Mohamed Nasir et al., 2018).

\subsection{Mediation}

The basic concept of mediation entails an independent and neutral third party assisting the disputants to work out for themselves a solution to their dispute. Originating in the late 1960s in the USA (Tackaberry, Marriott, \& Bernstein, 2003), mediation is now the mandatory first instance method of resolving disputes in some of the states in the USA (Tackaberry et al., 2003) and Canada as well as many other jurisdictions. Another development in the use of mediation is an increase in the flexibility in the styles in which it may be conducted. In complex cases of co-mediation, which involving two mediators acting together, they may offer advantages over mediation by a single mediator (Charlton and Dewdney, 2004).

The original impetus for the development of mediation is recognition within the more enlightened sections of business communities of the strong commercial cases for resolving disputes by assisted negotiation rather than by litigation or arbitration. Several other developments portend a continuing growth trajectory for mediation. These include civil reform in many countries aimed at improving access to justice, transfusion of the outcomes of the civil litigation reform initiatives into commercial arbitration, EU Directive on mediation of civil commercial disputes and globalization (Tembo and Ndekugri , 2016). 


\section{Fast Track Arbitration in Construction Industry}

Issues of speed and cost - efficiency drive to the heart of the arbitration procedure, and are frequently advocated as the core reason as to why arbitration so clearly surpasses litigation to a suitable choice of dispute resolution for business community, including the construction industry (Magnusson, 2001). Construction arbitration is intended to be economical and efficient, which results in a fair decision by the experts in construction and/or construction law, yet numerous of them fall short of achieving the first two goals (Overcash \& Gerdes, 2009). Due to this, fast track arbitration takes up the position to settle the disputes rapidly along with cost efficiency to resolve disputes. By using this approach, the disputants are encouraged to stick with the timeframe given and make proper agreement with the appointed arbitrator to commit with the case and resolve within the stipulated time (Nickles, 1991).

The essence of fast track arbitration is that the time limit is fixed for every action to be taken by the disputants or arbitrators. Penalties, liquidated damages and claims for damages safeguard the interest in the efficient realization of a project and ideally motivate the parties involved in the project to work under pressure to assure and achieve completion of the project on schedule (Baumhauer, 2018)

A number of arbitration institutions have adopted rules for fast track arbitration which are found to be the most wellknown international arbitration institutions, inter alia:

- American Arbitration Association (AAA)

- Geneva Chamber of Commerce and Industry (CCIG)

- China International Economic Arbitration Commission (CIETAC)

- Japan Commercial Arbitration Association (JCAA)

- World Intellectual Property Organization (WIPO)

- Arbitration Institute of Stockholm Chamber of Commerce (SCC)

The applicability of each institution differs based on methods used. The AAA, CIETEC and JCAA rules are effective for an automatic application if the amount in dispute does not exceed a certain threshold. In contrast, the CCIG, WIPO and SCC rules state that the parties have to make an explicit agreement that the rules should apply (Magnusson, 2001). It is further added that the parties are definitely free to exclude the application of the rules for fast track arbitration in their arbitration agreement.

In conclusion, the degree of success of any arbitral procedure, including fast track arbitration, relies to a large extent on the conduct of the parties in the course of proceedings. National law and procedural rules constitute an important infrastructure for an efficient and judicial procedure, however, at the end of the day, it depends on the party's loyalty to the procedure once chosen, essential for fast track arbitration's possibility to fulfil the task with which it is charged (Andrews, 2016).

\section{Methodology}

Data collected in this study consisted of primary data acquired from interviews. The first stage of data collection represented the primary data for this research that retrieved via in - depth semi - structured interview. The group of respondents determined for this semi - structured interview focused on twenty (20) Malaysian AIAC arbitrators covering the construction sector area. A list of arbitrator panelist was retrieved from the AIAC official website.

According to the information gathered, the selected respondents for the semi - structured interviews comprised of AIAC registered construction arbitrator. They are among the experts in managing arbitration in construction with an adequate experience in this field as well. As represented in Table 1.

Table 1 - Response Data

\begin{tabular}{cccc}
\hline Background & Description & No & $\begin{array}{c}\text { Percentage } \\
(\mathbf{\%})\end{array}$ \\
\hline Position & Civil Engineer & 3 & 15 \\
& Lawyer & 13 & 65 \\
& Project Manager & 1 & 5 \\
& Quantity Surveyor & 3 & 15 \\
\hline Background & TOTAL & $\mathbf{2 0}$ & $\mathbf{1 0 0}$ \\
& Construction Management & 1 & 5 \\
& Engineering & 3 & 15 \\
& (Civil/M\&E/Structural) & & 15 \\
& Quantity Surveying & 3 & 65 \\
\hline Law & 13 & $\mathbf{1 0 0}$ \\
\hline
\end{tabular}




\begin{tabular}{cccc}
\hline Years of Experience & Less than 5 years & 3 & 15 \\
& $5-10$ years & 5 & 25 \\
$10-20$ years & 3 & 15 \\
& More than 20 years & 9 & 45 \\
\hline TOTAL & $\mathbf{2 0}$ & $\mathbf{1 0 0}$ \\
\hline
\end{tabular}

Table 2 - Respondents experience in Construction Arbitration

\begin{tabular}{ccc}
\hline Respondents involvement & No & Percentage \\
\hline Less than 5 years & 8 & 40 \\
$5-10$ years & 5 & 25 \\
$10-$ 20 years & 6 & 30 \\
More than 5 years & 1 & 5 \\
\hline TOTAL & $\mathbf{2 0}$ & $\mathbf{1 0 0}$
\end{tabular}

In terms of involvement in the construction arbitration, the participating respondents represented institutions in this field from three years and more. Table 2 indicates that the least percentage of $5 \%$ shows only one respondent was involved in the construction arbitration for more than 20 years. While that $40 \%$, estimated around 8 respondents, were involved in construction arbitration, followed by $30 \%, 6$ respondents, and the remaining $25 \%$ with a total of 5 respondents who managed to get themselves involved as part of the construction arbitration

In the years of involvement in the construction arbitration, the respondents enquired on the existing fast track arbitration rules in Malaysia and all of them are under the Asian International Arbitration Centre (AIAC) registered construction arbitrator.

\section{Finding and Discussions}

\subsection{Roles of Malaysian Arbitral Institution and Construction Arbitrator in Assisting Fast Track Arbitration}

The adoption of the view of providing an alternative and flexible procedure to ensure a just, expeditious, economical and final determination of disputes has led to enhanced approaches in the application of cost - and time - effective manner of alternative dispute resolution (Mar \& Dass, 2012). Each construction dispute resolution has a crucial role to play to reduce construction dispute. Both arbitral institution and construction arbitrators should act as enablers to influence the application of fast track arbitration. Both entities are concerned to provide strong influence in ensuring the effectiveness of fast track arbitration. According to Davis (1999), arbitration agreements are a result of cooperation of two disagreeing parties who desire a fair and efficient method of dispute resolution including fast track arbitration. Arbitral institution and construction arbitrator are essential to give their attention in order to achieve the preferable dispute resolution by resolving the existing issues (Singh, 2017). Based on the research conducted by Queen Mary University of London (2015), the roles and position of arbitral institution as well as the construction arbitrator are seen as an indicator for established seats for arbitration in the construction industry.

Arbitral institution is regarded as the main pillars to resolve the issues concerning fast track arbitration (Rajoo, 2018). The proactive roles of arbitral institution include providing a procedural framework, specialized expertise and services, wherein parties can avail a well - tried and tested set of arbitration rules coupled with assistance from professional staff who are familiar with these rules (Wilske, 2015) Such example can be seen in France, where arbitration users are once again recognized by the International Court of Arbitration of ICC as the most preferred arbitral institution worldwide, and that the survey results are highlight by a significant margin (77\%) (Queen Mary University of London, 2018). Furthermore, it is pointed to the ICC's reputation, recognition and global presence as well as its international experience ability to take into account user's needs and preferences, as significant appealing factors for users as a leading arbitral institution (Chardonnal, 2018). In addition, other arbitral institutions have adopted a fast track option in their arbitration rules and keeps on striving to deliver new techniques on cost and time effective arbitration for construction disputes (Tymczyszyn, 2018). Timár (2013) also lists out the most typical services and powers undertaken by or transferred (granted) to arbitral institution are as follows:

- Selecting (appointing) and conforming arbitration, including the power to determine the number of arbitrators (serving as an appointing authority);

- Resolving challenges to arbitration and removing arbitrators (upon challenge/request or ex officio);

- Designating the place of arbitration;

- Fixing the initial language of proceedings (until the arbitral tribunal finally determines the language of arbitration); 
- $\quad$ Fixing the cost (fee) (advance), including the fees payable to the arbitrators, and ordering advance (interim) or final payments;

- $\quad$ Fixing or modifying time limits.

As a result, the predominant role of arbitral institutions in assisting fast track arbitration is crucial in reducing construction disputes and achieving preferable cost and time efficient dispute resolution in Malaysia. Nevertheless, achieving the preferable seats of arbitration, not only require involvement of arbitral institutions, but also cooperation from construction arbitrations, in achieving effective results in applying fast track arbitration. At an early stage of dispute, construction arbitrators are required to acknowledge fast track arbitration based on suitable cases to be handled in order to reduce construction disputes(Tymczyszyn, 2018). Hence, Wilske (2015)further lists out roles of construction arbitrators in the application of fast track arbitration as follows:

- Adequate expertise, whether legal or industry specific

- Impeccable integrity

- Compliance with issues of confidentiality

- Fair and equal treatment of the parties

- Impartiality and objectivity

- Ability to arrive at and draft a reasoned award

- Ability to render an award in a timely manner

- Ability to preside over an arbitration including administering the process of the arbitration in a timely and efficient manner

- $\quad$ Adequate knowledge and experience of arbitration and the arbitral procedure.

Thus, the proposed recommendation suggests that the arbitral institution and arbitrators play a significant role in the application of fast track arbitration in Malaysia. Due to the existing issues, arbitral institutions need to take the first leap to further enhance the application of fast track arbitrations among parties involved. However, the respondents recommended that construction arbitrators play their roles in terms of practices, and be aware of the fast track arbitration applied by arbitral institution.

\subsection{Enhanced Fast Track Arbitration in Malaysia}

The existing application of fast track arbitration in Malaysia is relatively inefficient and needs further enhancement in terms of encouragement and application. In fact, it is the utmost significance to identify the root problem in every issues to be solved and the challenges that hinder from achieving effective fast track arbitration. Thus, there is a need to identify the related issues, which are necessary to achieve cost and time effective dispute resolution practice. Some issues were highlighted regarding the existing fast track arbitration in Malaysia are the lack of encouragement, insufficient guidelines and technique among arbitral institutions, as well as inadequate arbitrators with strong case management skills for fast track arbitration.

Inefficient fast track arbitration leads to significant impacts to the construction industry, and should be resolved wisely to utilize the effectiveness of construction disputes (Mustaffa \& Danuri, 2012). Hence, there is a need for arbitral institutions to take into account the existing issues in enhancing the application of fast track arbitration in Malaysia, and cooperation with construction parties in achieving cost and time effective dispute resolution. Moreover, the primary roles of arbitral institutions are to encourage and provide guidelines and techniques in time and cost control. Besides, the respondents suggested encouragement of the existing fast track arbitration. The quotation of the above analysis is provided below;

"The fast track arbitration has been provided by AIAC. Unfortunately, they are not being applied in the construction industry. Arbitral institutions need to provide guideline or technique in controlling time and cost to encourage the existing fast track arbitration because it will motivate the parties to use it."

The techniques provide guidance to the parties and their arbitral institutions on fast track arbitration procedures to be able to agree upon efficient management of proceedings (Wolrich, 2007). In addition, the author added that the techniques suggested in the document are not intended to be exhaustive, and encourage the parties to utilize it.

Based on the results from the existing issues pertaining to the existing fast track arbitration in Malaysia, several recommendations were given as solutions to the issues. Marchisio (2018) stated that arbitral institutions need to guide and manage the usage of fast track arbitration to be shorter, quicker, and less expensive without undermining the work. With the urge of expediency, a sole arbitrator is suitable, and will be able to cover shorter timeline with a faster case management tool such as fast track arbitration (Bell \& Steensma, 2017). Hence, it is necessary to create suitable schedule and timeline of fast track arbitration from other developed countries as a basis for further enhancement in existing fast track arbitration. Besides, it is agreeable by the respondents, mentioning on the need for special provision in fast track arbitration. While in other developed countries, they have created provisions to assist the creation of schedule and timeline in expedited proceedings (Lisa, 2018). Such example can be seen in one of the developed country, where the International Chamber of Commerce (ICC) has provided provision in their reports on techniques for controlling time and costs in arbitration (Wolrich, 2007) Lastly, one of the respondent did suggest; 
"To ensure fast track arbitration is effectively utilized, arbitral institutions should create or assist the parties on suitable timeline and schedule with the guidance provided from the provisions with the effort from arbitral institution."

The third issue that arises is the insufficient of arbitrators with strong case management skills for fast track arbitration. Although there are numerous arbitrators in the construction industry, there is still insufficient number of arbitrators that are ready for the usage of fast track arbitration It is due to the highly pressured environment (Leon, 2019). Under these circumstances, it is vital to have a construction arbitrator that strong in case management skills, experience in the technical matters in dispute and the availability time to be rendered by the tribunal. Therefore, it is crucial to have arbitrator that is committed and competent to complete this cost and time effective dispute resolution.

\subsection{Awareness Among Malaysian Construction Arbitrators Towards the Existing Fast Track Arbitration}

Most construction arbitrators are not aware of the existence of fast track arbitration. This is supported by the practitioners on the field Singh (2018) who emphasized that there is lack of awareness on fast track arbitration among construction arbitrators in Malaysia. This is because arbitral institutions are not informed on the existence of existing fast track arbitration. Besides that, the respondents feel that the level of awareness among construction arbitrators is low due to lack of encouragement by arbitral institution, Multiple authors have addressed this issue of awareness on the application of fast track arbitration that hinders the effectiveness of fast track arbitration practices (Premaraj, 2018; Rajoo, 2018; Singh, 2018).Furthermore, Premaraj (2018) added that the major barrier of fast track arbitration applied in construction industry is the lack of awareness among local construction arbitrators on cost and time effective techniques and approaches. Consequently, multiple recommendations are retrieved from qualitative analyses to ameliorate the current standings of the level of awareness among construction arbitrators.

As for the first step towards solving the problem of awareness among construction arbitrators would be the support from arbitral institutions. Moreover, seminars, awareness campaigns and workshops has emphasized on the importance of fast track arbitration, to be conducted in order to enhance the knowledge on fast track arbitration in Malaysia. By implementing the guidelines and techniques on fast track arbitration, the efforts in promoting fast track arbitration would be fully achieved. The Asian International Arbitration Centre (AIAC) is responsible to make further action in increasing level of awareness among the construction arbitrators in applying fast track arbitration for cost and time effective dispute resolution in the construction industry(Wilske, 2015). It is vital to mitigate this issue by conducting workshops, conferences, seminars, and exhibition to upsurge the awareness on existing application of fast track arbitration, sharing knowledge and attract construction parties towards fast track arbitration practices. According to Khan, Liew, \& Ghazali (2014) construction parties, especially construction arbitrators, need to be aware of existing application of fast track arbitration by attending seminars, conferences, workshops and talks conducted by arbitral institutions. Thus, it will slowly will encourage construction arbitrators to apply fast track arbitration effectively and provide benefit for controlling cost and time of arbitration.

In the efforts of raising awareness among construction arbitrators and other parties on cost and time - effective dispute resolution, the Asian International Arbitration Centre (AIAC) has conducted a talk towards expedited proceedings 1 to enhance the understanding and knowledge on the application of fast track arbitration proactively and techniques of controlling time and cost. It is one of the initiatives of arbitral institution to ensure that cost and time effective dispute resolution to be practiced and adapted in the Malaysian construction industry. Therefore, it is suggested that the AIAC to conduct seminar and talk which focus on delivering the knowledge and guide construction arbitrator towards the existing application of fast track arbitration in order to enhance the level of awareness among construction arbitrators. The increase of awareness among construction arbitrator towards fast track arbitration would lead to the cost and time effective dispute resolution in construction industry. Besides, another recommendation suggested by the respondents to enhance the application of arbitral institution with regards to fast track arbitration is by encouraging and increasing the awareness among construction parties on the need to take into account the knowledge and guidance to assist the current practices among the construction arbitrator in handling construction dispute.

\subsection{Practices Among Construction Arbitrator in Applying Fast Track Arbitration}

According to Leon (2019), the common practices of construction arbitrators in utilizing fast track arbitration are relatively low and discouraged. The author also add that construction arbitrators need to be fully prepared for the application of fast track arbitration which gives confidence when using it. As reported in qualitative analyses, majority of the interviewed construction arbitrators are not preferable in using fast track arbitration, which shows that the level of awareness and knowledge among construction arbitrators are still low. Based on previous research conducted in developed countries, the application of fast track arbitration evidently gives positive impacts and benefits to the parties in terms of expeditious proceeding, cost and time effective dispute resolution (Slate, 2010). In addition, Bell \& Steensma (2017) agreed that the benefit of effectiveness of fast track arbitration practices lead to cost and time effective arbitration. 
Therefore, a few suggestions are proposed to address the issues discussed. The construction arbitrators are recommended to provide a reasonable timeline in terms of application of fast track arbitration to reduce construction disputes in the construction industry. According to Leon (2019), the timeline of fast track arbitration are tight and the awards need to be published approximately within six(6) months. Henceforth, proper and reasonable timeline is crucial to provide better working and economic environment as a whole. Marchisio (2018) pointed out that reasonable timeline practices in fast track arbitration can reaffirm the basic principle that arbitration is speedy and more cost effective over litigation in regards to minimizing construction disputes. Moreover, having a high degree of cooperation and team work from the parties and construction arbitrator on adherence to timeline is also required to ensure the effectiveness in using fast track arbitration (Leon, 2019). Hence, the quantity of construction disputes can be reduced.

Aside from that, another recommendation given to elevate this issue is that construction arbitrators need to have strong case management skill and experience in technical matters in dispute. At the same time, the availability of time to be rendered by the tribunal is also needed in order to apply fast track arbitration swiftly and effectively. In addition, arbitration counsel is needed for guidance and assistance for the application of fast track arbitration to be practiced in the construction industry. Thus, all construction parties have the responsibility to utilize fast track arbitration effectively. Consequently, the arbitral institution needs to encourage construction arbitrator to apply fast track arbitration in the construction industry.

\subsection{Framework to Further Enhance the Application of Fast Track Arbitration in Malaysian Construction Industry}

Eight important impediments identified were expectancy of long arbitration award, lack of encouragement from arbitral institution, flexibility of fast track arbitration, lack of competent arbitrator, lack of altruism, cooperation from parties, lack of awareness of fast track arbitration and lack of practices as shown in Figure 1. The recommendations suggest that arbitral institutions and construction arbitrators play a significant role to apply fast track arbitration effectively to achieve the cost and time effective dispute resolution as shown in Figure 2.

Both arbitral institution and construction arbitrators need to be proactive to resolve the issues. Besides, arbitral institutions also acquire support from construction parties to apply fast track arbitration in the construction industry. Arbitral institutions are required to encourage by providing guidelines for procedural timeline of arbitration award and technique for controlling time and cost. The roles of arbitral institution in the application of fast track arbitration are by embedding the duties of setting up rules, domestic and international, to the parties involved. Additionally, the flexibility of fast track arbitration may attract construction parties to use it by having competent and altruistic construction arbitrator by arbitral institution. Meanwhile, cooperation of parties is ultimately crucial to contribute to technical competence and may devote time to conduct the proceedings on a relatively short notice, and publish the award within such tight schedule. Apart from that, awareness on the existing fast track arbitration is vital in ensuring the effectiveness of tools including awareness, workshop, seminar and others on the importance of fast track arbitration suggested to be conducted. The purpose of awareness program for construction arbitrators is to develop knowledge on fast track arbitration in Malaysia. Lastly, suggestions on the practices among construction arbitrators are highlighted. Construction arbitrators recommend practicing cost and time effective arbitration in the construction industry. By applying fast track arbitration effectively, a country can become a cost - and time effective dispute resolution centre.

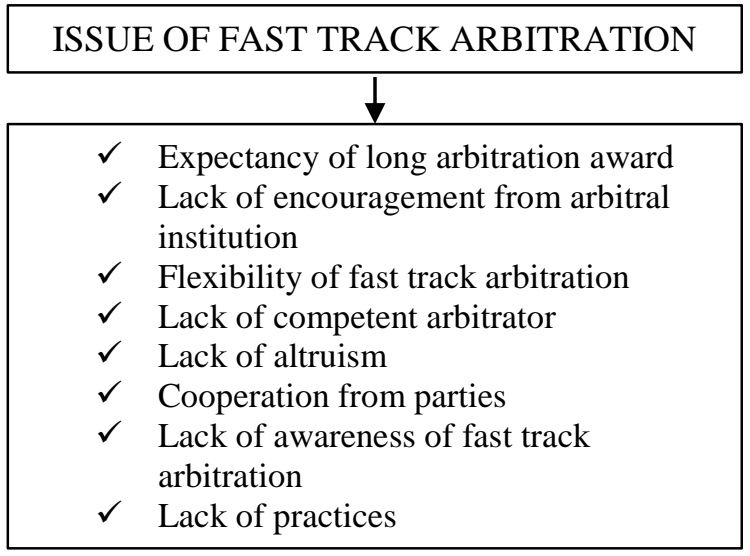

Fig. 1 - Issue of Fast Track Arbitration 


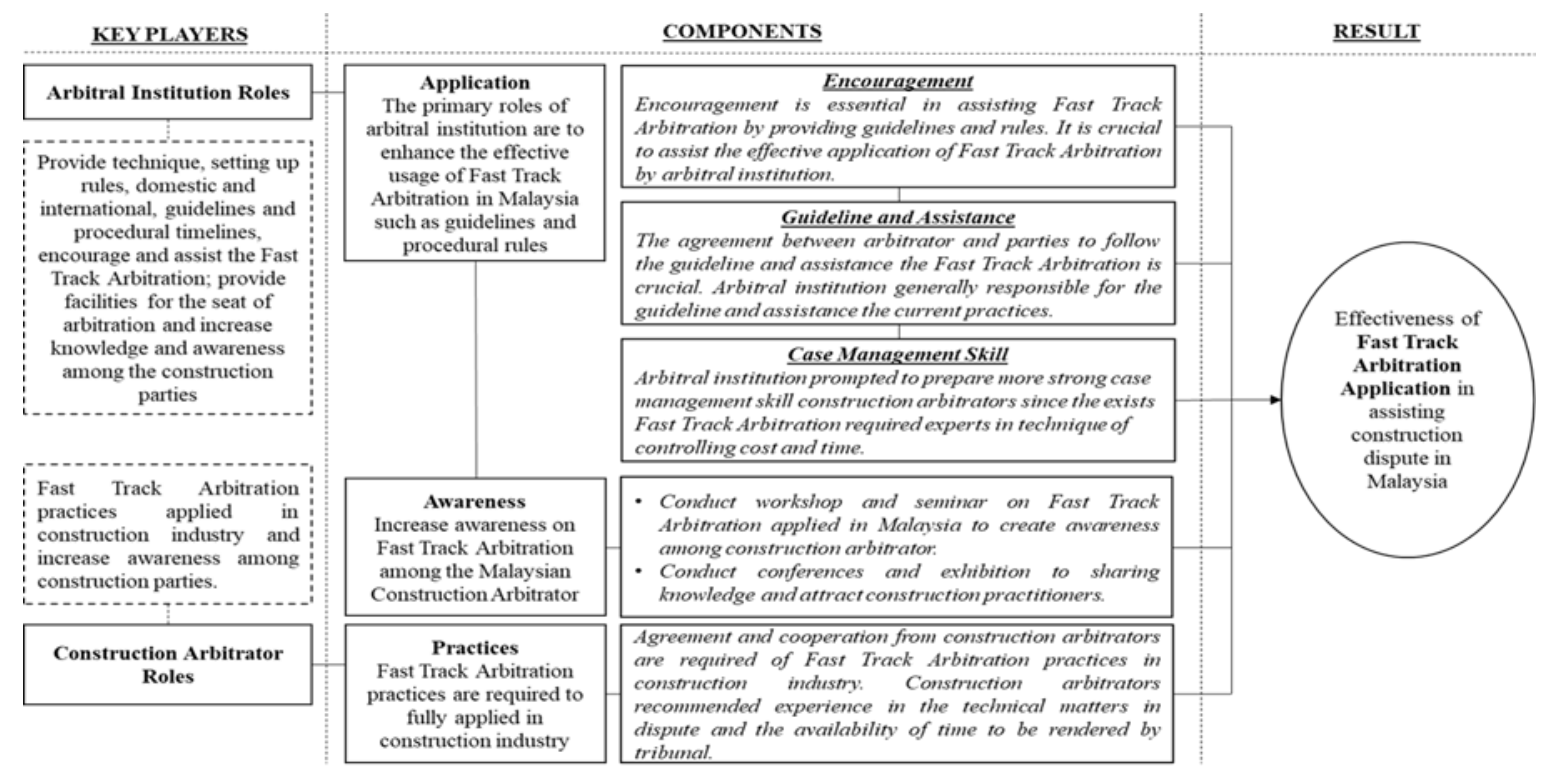

Fig. 2 - Framework to Further Enhance the Application of Fast Track Arbitration in Malaysian Construction Industry

\section{Conclusion}

In conclusion, the application of fast track arbitration in Malaysia remains relatively low in comparison to those in developed countries. From the data collection administered for this study, the effectiveness of the application of fast track arbitration among the parties and arbitral institutions is enquired. Most respondents agreed that the application of fast track arbitration in the Malaysian construction industry has been low and ineffective. In fact, some common problems faced by the parties and arbitral institutions have been due to lack of encouragement, lack of awareness, as well as lack of practices and strong case management skill. Lastly, the application of of fast track arbitration in Malaysia needs to be further enhanced to ensure a time and cost-effective dispute resolution that benefits all parties for a better business and commercial relationship, thus enhancing the contractual relationship of all construction parties and future contracts.

\section{Acknowledgement}

The authors sincerely acknowledge Universiti Teknologi MARA for their financial support under the grant 600IRMI 5/3/GIP (060/2019).

\section{References}

AIAC. (2018). About AIAC.

Andrews, N. (2016). The Foreign Party's Choice Between Arbitration and Court Litigation in The Culture of Judicial Independence in a Globalised World. https://doi.org/https://doi.org/10.1163/9789004307087_021

Baumhauer, M. (2018). Time is of the Essence - the Case for Fast Track Arbitration.

Bell, A., \& Steensma, A. (2017). Expedited Arbitration and The Future of International Construction Disputes. London. Retrieved from http://www.cms-lawnow.com/-/media/lawnow/pdfs/cms-publications/s-17100032880-gric-v4expedited-arbitration-article.pdf?la=en\&hash=D3608CC36AE21B5B7FE6FB8319E2238B258F4958

Besaiso, H., Fenn, P., \& Emsley, M. (2018). Evolution of Construction Arbitration. Journal of Legal Affairs and Dispute Resolution in Engineering and Construction, 10(2), 1-10. https://doi.org/10.1061/(ASCE)LA.1943-4170.0000248.

Chardonnal, D. (2018). Major survey confirms ICC as preferred arbitral institution in all continents. International Chamber of Commerce (ICC), pp. 1-2.

Charehzehi, A., Chai, C. S., Md Yusof, A., Chong, H. Y., \& Loo, S. C. (2017). Building information modeling in construction conflict management. International Journal of Engineering Business Management, 9, 1-18. https://doi.org/10.1177/1847979017746257

Cox, A., \& Thompson, I. (1997). "Fit for purpose" contractual relations: Determining a theoretical framework for construction projects. European Journal of Purchasing and Supply Management, 3(3), 127-135. https://doi.org/10.1016/S0969-7012(97)00005-1

Davis, K. R. (1999). A Model for Arbitration: Autonomy, Cooperation and Curtailment of State Power. The Fordham 
Urban Law Journal, 26(2), 167.

Fenn, P., Lowe, D., \& Speck, C. (1997). Conflict and dispute in construction. Construction Management and Economics, 15(6), 513-518. https://doi.org/10.1080/014461997372719

Gaitskell, R. (2007). International statutory adjudication: Its development and impact. Construction Management and Economics, 25(7), 777-784. https://doi.org/10.1080/01446190701499609

Garner, B. A. (1999). Black's Law Dictionary (Seventh Edition).

Gerber, P., \& Serra, D. (2011). Construction litigation: Are we doing it better? Melbourne University Law Review, 35(3), 933-970.

Guney, F. H. O. S. E. N. L. (2018). Time is of the essence: the evolving platform for fast track arbitration. Retrieved from http://arbitrationblog.practicallaw.com/time-is-of-the-essence-the-evolving-platform-for-fast-trackarbitration/

Karape, A. M., \& Joshi, A. M. (2018). Dispute Resolution in Construction Industry. International Journal of Science Technology \& Engineering (IJSTE), 5(6), 1-9.

Khan, R. A., Liew, M. S., \& Ghazali, Z. Bin. (2014). Malaysian Construction Sector and Malaysia Vision 2020: Developed Nation Status. Procedia - Social and Behavioral Sciences, 109, 507-513. https://doi.org/10.1016/j.sbspro.2013.12.498

Leon, W. S. (2019). Continiuing Towards The Horizon (A New Director, A Strong Foundation) - Fast Track Arbitration in Practice.

Lim, C. F. (2014). Resolution of Construction Industry Disputes: Arbitration, Statutory Adjudication or Litigation in the Construction Court? Azman, Davidson \& Co., (January 2014), 1-11. Retrieved from http://www.azmandavidson.com.my/resolution-of-construction-industry-disputes-arbitration-statutoryadjudication-or-litigation-in-the-construction-court/

Lisa, A. (2018). Expedited arbitration: Paris v Stockholm: full steam ahead. Retrieved from http://arbitrationblog.practicallaw.com/expedited-arbitration-paris-v-stockholm-full-steam-ahead/

Magnusson, A. (2001). Fast Track Arbitration - The SCC Experience.

Mar, S. W., \& Dass, D. (2012). KLRCA's fast track rules for resolving contract disputes.

Marchisio, G. (2018). Recent Solutions to Old Problems: A Look at the Expedited Procedure Under the Newly Revised ICC Rules of Arbitration. Ssrn, (1), 76-83. https://doi.org/10.2139/ssrn.3092128

Mohamed Nasir, N. I. I., Ismail, Z., \& Muhammad Fadhullah Ng, N. K. (2018). Comparative Analysis on Construction Adjudication Systems Towards Effective Implementation of Statutory Adjudication in Malaysia. Malaysian Journal of Civil Engineering, 30(2), 202-216.

Mustaffa, N., \& Danuri, M. (2012). A revisit on the current practice of dispute resolution and ADR in Malaysia construction industry. Journal of Design and Built Environment, 1(10), 1-13. Retrieved from http://eprints.utm.my/30600/1/NurEmmaMustaffa2012_ARevisitontheCurrentPracticeofDisputeABS.pdf\%5Cnht tp://eprints.utm.my/30600/

Nee, T. S., Nadarajan, S., \& Whyte, A. (2013). Reviews of Cases of Construction Disputes in Malaysia and its Relation with Standard Form of Construction Contract. Advanced Materials Research, 831, 191-196. https://doi.org/10.4028/www.scientific.net/amr.831.191

Nickles, P. J. (1991). Fast-Track Arbitration: A Claimants Perspective. The American Review of International Arbitration, 2(2), 1-2.

Overcash, A. L., \& Gerdes, E. L. (2009). Five Steps to Fast-Track The Large, Complex Construction Case. Dispute Resolution Journal, 64(2), 1-2.

Premaraj, B. (2018). CIPAA : Adjudication Leading the Way?

Queen Mary University of London. (2015). Queen Mary 2015 International Arbitration Survey: Improvements and Innovations in International Arbitration. London. Retrieved from http://www.arbitration.qmul.ac.uk/docs/164761.pdf

Queen Mary University of London. (2018). 2018 International Arbitration Survey: The Evolution of International Arbitration Executive summary.

Rajoo, S. (2017). KLRCA Annual Report 2017. Asian International Arbitration Centre (AIAC), 1-45.

Rajoo, S. (2018). Construction sector sees a higher number of dispute cases. Asian International Arbitration Centre (AIAC), pp. 3-5. Retrieved from https://themalaysianreserve.com/2018/04/25/construction-sector-sees-a-highernumber-of-dispute-cases/

Saad, M., Jones, M., \& James, P. (2002). A review of the progress towards the adoption of scm relationships in construction.pdf. European Journal of Purchasing and Supply Management, 8, 173-183.

Singh, H. (2017). Construction Dispute Avoidance: The First Line of Defence in Contractual Dispute Management \& Resolution. Retrieved April 12, 2017, from http://www.cidb.gov.my/images/content/pdf/ucapan/2017/Construction-Contract-Management-Opening-Speechby-Dato-Ahmad-Asri.pdf

Singh, H. (2018). CIPAA - The Adjudication Process - Is Adjudication a Fast-Track Arbitration? - Ir. Harbans Singh K.S. 
Slate, W. (2010). Cost and Time Effectiveness of Arbitration. Contemporary Asia Arbitration Journal, $3,182$.

Tackaberry, J., Marriott, A., \& Bernstein, R. (2003). Bernstein's Handbook of Arbitration and Dispute Resolution Practice.

Tazelaar, F., \& Snijders, C. (2010). Dispute resolution and litigation in the construction industry. Evidence on conflicts and conflict resolution in The Netherlands and Germany. Journal of Purchasing and Supply Management, 16(4), 221-229. https://doi.org/10.1016/j.pursup.2010.08.003

Tembo C, Ndekugri I, H. F. (2016). Practice and Procedure in the Mediation of Construction Industry Disputes : An Exploratory Study, (April), 203-214.

Timár, K. (2013). The Legal Relationship between the Parties and the Arbitral Institution. ELTE Law Journal, 1(1), 103122.

Tymczyszyn, I. (2018). Corporate and commercial disputes review.

Wilske, S. (2015). The Duty of Arbitral Institutions to Preserve the Integrity of Arbitral Proceedings. Contemporary Asia Arbitration Journal, 1(1), 8-23. https://doi.org/10.3868/s050-004-015-0003-8

Wolrich, P. M. (2007). Techniques for Controlling Time and Costs in Arbitration - Report from the ICC Commission on Arbitration. International Chamber of Commerce (ICC). 